\title{
BIODIVERSITY SINCE RIO: THE FUTURE OF THE CONVENTION ON BIOLOGICAL DIVERSITY
}

Kal Raustiala and David G. Victor

International Institute for Applied Systems Analysis

Laxenburg, Austria

RR-96-15

October 1996

Reprinted from Environment, Volume 38, Number 4, May 1996.

INTERNATIONAL INSTITUTE FOR APPLIED SYSTEMS ANALYSIS

Laxenburg, Austria 
Research Reports, which record research conducted at IIASA, are independently reviewed before publication. Views or opinions expressed herein do not necessarily represent those of the Institute, its National Member Organizations, or other organizations supporting the work.

Environment, Volume 28, Number 4, pp. 16-20 and 37-45. Reprinted with permission of the Helen Dwight Reid Educational Foundation. Published by Heldref Publications, 1319 Eighteenth St., N.W., Washington, D.C. 20036-1802. Copyright (C)1996.

For copyright reasons the photographs that appeared in the original version have been omitted from this reprint.

All rights reserved. No part of this publication may be reproduced or transmitted in any form or by any means, electronic or mechanical, including photocopy, recording, or any information storage or retrieval system, without permission in writing from the copyright holder.

Printed by Novographic, Vienna, Austria. 


\section{Foreword}

What happens to international environmental agreements once they are signed, and how does the implementation of such agreements influence their effectiveness? These are the questions that motivate the Implementation and Effectiveness of International Environmental Commitments (IEC) Project at the International Institute for Applied Systems Analysis (IIASA).

In this essay, reprinted from Environment, Kal Raustiala and David G. Victor review developments within the Convention on Biological Diversity since its adoption in 1992 at the United Nations Conference on Environment and Development in Rio de Janeiro. They also analyze the prospects for future implementation. The biodiversity agenda has expanded to include issues such as intellectual property rights and the regulation of the biotechnology industry.

The authors caution that while the need for a comprehensive approach is important, the core issues that first inspired creation of the Convention - the preservation, conservation, and utilization of biological resources - risk being overshadowed by conflicts engendered by the agenda's expansion. Greater focus is needed on establishing a well-functioning system of implementation review, as well as greater attention to important biodiversity-rich habitats such as coral reefs, wetlands, and forests.

Prof. Eugene B. Skolnikoff Project Co-leader International Environmental Commitments Project 
Biodiversity Since Rio

\section{The Future of the Convention on Biological Diversity}

$B$ iodiversity is the diversity of species, genetic material, and ecosystems or, more generally, "the variability among living organisms." Loss of biodiversity may pose the world's greatest ecological danger. Diversity is a foundation of natural ecosystems. Each distinct species is a unique evolutionary milepost that cannot be replaced once it is lost. By many measures, the pace of destruction is fast and rising, primarily as a consequence of habitat destruction. Concerned about these trends, various environmental organizations and governments sought negotiation of a global treaty to protect all forms of biodiversity. The Convention on Biological Diversity (CBD) was opened for signature in 1992 at the United Nations Conference on Environment and Development (UNCED) in Rio de Janeiro. This article describes the problem of biodiversity loss, charts how the biodiversity agenda has expanded to include many other concerns such as access to genetic resources, intellectual property rights, and biotechnology, and reviews the operation of the $C B D$ and its prospects.

\section{The Biodiversity Problem}

A central feature of the biodiversity debate is the recognition that diversi-

\section{By Kal Raustiala and David G. Victor}

ty is important coupled with disagreement over the exact definition of biodiversity and the extent of the crisis. ${ }^{2}$ Most of the scientists working on the issue believe that today's storehouse of biological resources is being rapidly depleted as human development increasingly encroaches on unique natural habitats that are rich in biodiversity. The vast majority of this diversity is unknown to modern science: The 1.7 million described species represent only a small fraction of the likely total, which is estimated to be between 4 and 111 million species. ${ }^{3}$ A total of 1,622 extinctions have been documented since 1600 , and 26,106 species are currently considered "threatened." Some claim that extinctions are currently occurring at rates nearing those of the great natural catastrophes of the Paleozoic and Mesozoic eras. The natural background rate of extinction is approximately 1 species per year, while the current rate is perhaps 100 or 1,000 times higher. ${ }^{6}$ The extinction rate will multiply 10 -fold if all of the currently threatened species become extinct over the next century. ${ }^{7}$ Others take a more sanguine view, however. Using similar data but com- paring the number of species lost with the overall pool of species, they conclude that the extinction rate is low, perhaps 0.027 percent per year (or less than 1 percent over 30 years). ${ }^{8}$ Lack of systematic data the biodiversity problem. ${ }^{9}$

The number of species is a commonly used measure of diversity. But other measures may better reflect the characteristics of diversity that are most important and thus be more useful in setting biodiversity protection priorities. ${ }^{10}$ Alternatives include diversity in genetic code and taxa, as well as habitat measures that give special attention to mega-diverse areas. The policy implications differ depending on the particular measure that is selected. A species diversity measure directs policy to protect endangered or threatened species while a genetic diversity measure gives priority to species with especially different genes and recognizes that some species are more important than others. In general, however, neither of these measures has been used remains a central obstacle to defining 
rigorously to set real policy priorities, which have tended to focus either on absolute protection (e.g., prohibition of activities that would further threaten already endangered species), the creation of nature reserves, or special protection for species with high public appeal.

Humans contribute to the loss of biodiversity in many ways, including conversion of natural habitats, pollution, overfishing, and changing the climate. ${ }^{11}$ Much attention has been devoted to the conversion of biologically rich tropical forests. Scientists have shown that biodiversity is affected not only when wide swaths of virgin forest are cleared but also when ecosystems are excessively fragmented. One study of the Amazon basin, $f_{0 i}$ instance, found that the area of fragmented forest is nearly three times greater than the actual deforested area. ${ }^{12}$ Even dominant species, which might be expected to survive in moderately fragmented habitats, are likely to perish under such conditions. ${ }^{13}$

The case for protecting biodiversity has many dimensions. The direct economic returns-mainly in pharmaceutical, agriculture, and biotechnologyare numerous, though prone to overstatement. ${ }^{14}$ The number and value of drugs such as aspirin and taxol (first identified in the wild but now synthesized) are likely to be small. ${ }^{15}$ Examples abound of crop-threatening diseases such as wheat rust for which resistant strains were found in the wild, protected in gene banks, and crossbred into domesticated species. More productive and disease-resistant crop species have ailowed agricultural production to grow faster than the human population even though the amount of land devoted to agriculture has remained roughly constant. $^{16}$ While many biodiversity-rich forests have been harvested for timber, a recent study of the Peruvian rain forest calculated that the net present value of sustainable rubber, fruit, and timber harvests is $\$ 6,820$ per hectaremore than six times the mill value of clear-cut timber. ${ }^{17}$ Sustainable uses that protect biodiversity can clearly be cost-effective, although the value of forests (which is based on location, markets, and products) may vary by a factor of $400 .^{18}$
Diversity also offers many indirect benefits. Diverse ecosystems are more resilient against genetic defects such as vulnerability to disease and pests. It has long been thought that simple ecosystems are less stable than complex ones. ${ }^{19}$ Controlled experiments strongly suggest that reduced biodiversity may also lower the productivity of ecosystems. ${ }^{20}$ Methods for analyzing these indirect benefits are wellknown, but in practice valuing the full benefits of biodiversity is difficult and contentious. $^{21}$

Because the instrumental benefits of biodiversity are uncertain and difficult to assess, the strongest case for preserving it may be its intrinsic value. The sheer number of species makes the marginal value of any individual species small (except in extraordinary cases, such as taxolproducing trees, that are virtually impossible to identify a priori). But conceived holistically, biodiversity is essential to life as we know it, and outside narrow limits it may be inappropriate to compare marginal costs and benefits. ${ }^{22}$ Further, because extinctions are truly irreversible, current generations may have a special role in passing on the planet in substantially the same condition as they received it. ${ }^{23}$

Thus, while the economics are often indeterminant, the ethical conviction that biodiversity is valuable in its own right provides a major impetus for protecting it. This conviction is reflected in the opening sentence of the $C B D$, which refers to the "intrinsic" value of biodiversity. ${ }^{24}$ The central role of ethics and the many potential uses of biodiversity (combined with weak arguments about what specifically to protect and how to do it) constitute the main obstacle to effective implementation of the $\mathrm{CBD}$, however: It isn't always clear what to do and how to set priorities. This feature sets the biodiversity issue apart from international efforts to deal with ozone depletion, acid rain, hazardous waste, and many other environmental concerns - even climate change-where the problem is better defined and thus the menu of policy choices better focused.

\section{Setting the Biodiversity Agenda}

Preserving endangered species has long been a goal of international law. The first wildlife treaty, the Convention for the Protection of Birds Useful to Agriculture, dates to $1902 .{ }^{25}$ Today, several dozen international treaties protect particular species or vital habitats usually denominated in a set of lists. ${ }^{26}$ Several international organizationsnotably the quasi-nongovernmental World Conservation Union (IUCN) and the nongovernmental World Wide Fund for Nature (WWF) - have long been active in identifying endangered species, developing policy solutions, promoting the creation of protected areas, raising funds, implementing projects, and even helping to initiate and manage international treaties. ${ }^{27}$

The creation of the CBD stemmed from a perceived need for a treaty that would encompass all the extant conservation accords and provide a coherent framework for coordinated action to preserve biodiversity worldwide. ${ }^{28}$ Just as ecology has evolved from a frag. mented to a holistic study of ecosystems, ${ }^{29}$ so international law has embraced a holistic approach. Whether the accompanying gains are worth the added complexity remains an open question, however.

The biodiversity problem began to receive extensive scientific and media attention in the 1980s, much of it focused on the rapid destruction of tropical moist forests. Many leading tropical ecologists became publicists who argued that this generation's task was to save tropical wildlands. ${ }^{30}$ Public appeals by scientists in the popular press lent a sense of crisis to the biodiversity problem. While the influence of experts in environmental cooperation is often overstated, in this case scientists, lawyers, and policy activists played the central role in placing biodiversity protection on the international agenda. The 1980s offered a window of opportunity ${ }^{31}$ through which activist experts pushed the biodiversity problem and their favored international solution: a new treaty that would protect biodiversity as a global stock, including the many unexplored species and ecosystems. This approach con- 
trasted sharply with earlier treaties that focused only on particular named species and habitats. Within industrialized countries, the constituency for nature conservation was active and the political climate favorable to new biodiversity initiatives.

IUCN and the nongovernmental World Resources Institute (WRI) played leading roles in the effort to promote a biodiversity treaty and prepared numerous background papers, policy strategies, and even a draft treaty text. Building on this preparatory work and responding to pressure from industrialized countries, in 1987 the governing council of the United Nations Environment Programme (UNEP) resolved to create a working group to explore such a convention. ${ }^{32}$ In 1991-contemporaneous with the negotiations on the Framework Convention on Climate Change (FCCC)-formal multilateral negotiations began on the CBD. A 16-month deadline for finishing the work was set so that the treaty would be complete in time for UNCED.

The rapid negotiations were marked by an unwieldy agenda and conflict over the central objectives and priorities of the treaty. For industrialized countries, the goal was to promote conservation (though, as discussed below, this key concept is never actually defined in the treaty). For developing countries, the goal was broader: the sustainable use of biological resources, financial and technological transfers to assist in biodiversity protection, and the equitable distribution of the economic benefits of biological resources. The ever- broader agenda allowed packaging of many issues into an omnibus negotiation. As in the Law of the Sea negotiations, a central aim of the developing countries has been to channel Northern interest in natural resources toward the creation of mechanisms for wealth and technology redistribution. ${ }^{33}$

Environment and development turned out to be a volatile mix. While the expanded agenda potentially created greater scope for package deals, the negotiations sailed swiftly onto the shoals of North-South discord. The UNCED deadline allowed little time for compromises. Within the U.S. gov- ernment, the biodiversity issue was increasingly dominated by conservatives who were dubious about the problem and fearful that the treaty would influence debates over domestic environmental protection. ${ }^{34} \mathrm{~A}$ memo from Vice President Dan Quayle's influential competitiveness council, leaked in April 1992, urged that the United States not sign the treaty without fundamental redrafting. The final negotiating session in May of that year crammed in an enormous number of topics, many of them aimed at making the treaty satisfactory to the United States. The final document was necessarily a pastiche of vague commitments, ambiguous phrases, and some awkward compromises. Nonetheless, the treaty enjoys wide membership. A total of 156 nations signed the CBD at UNCED; enough formally confirmed their commitment and became parties to the treaty through ratification that it entered into force a mere 18 months later. By the end of 1995 there were 127 parties.

The CBD's popularity stems in part from the United States' initial refusal to sign it. While incurring the wrath of environmentalists and diplomats the world over, U.S. hesitance also made signature and ratification a popular act of protest in many other nations. Modest commitments that can be interpreted in many ways also account for high membership in the treaty. Countries rich in biodiversity (primarily developing countries) see the CBD as a way to reaffirm their sovereign right to their genetic resources and to promote a more equitable sharing of the benefits from biodiversity. ${ }^{35}$ Of the first 30 ratifications needed to bring the treaty into force, all but 5 were by developing countries; only one was by a major power-Japan. ${ }^{36}$ All industrialized countries acknowledged that the treaty had many flaws, mostly stemming from the expanded agenda, but only the United States elected to remain outside. (President Bill Clinton has since signed the $\mathrm{CBD}$, but ratification remains stalled in Congress.)

\section{Commitments of the Convention}

The CBD is a landmark in that it is the first global treaty to explicitly take a comprehensive, ecosystems-based approach to the protection of biodiversity. It also reaffirms state control over biological resources within national territories, while simultaneously noting that biodiversity is the common concern of all. (Resolving these two sometimes conflicting claims remains a major challenge.) The central objectives of the treaty are threefold: the conservation of biological diversity, the promotion of its sustainable use, and the equitable sharing of the benefits of genetic resources. It is the last objective, with its clear redistributive implications, that was and remains the cause of much diplomatic strife. The basis of the perceived North-South bargain was summarized in the words of one developing country participant: "We have the biodiversity, they have the technology." ${ }^{37}$ The commitments made by participants may be grouped into four clusters that reflect the major issues.

\section{Direct Conservation Obligations}

The CBD is a true framework treaty. Aspirational in tone and well salted with caveats, it contains no targets, timetables, or lists of any kind. Some countries (led by France) pushed for lists of special areas, and their absence is viewed as a failing by some observers.

Each party to the CBD is obligated to develop national programs for the conservation and sustainable use of biodiversity "in accordance with its particular conditions and capabilities." ${ }^{38}$ Parties must monitor components of biodiversity and activities that are particularly deleterious, establish a system of protected areas, regulate their resources, and rehabilitate degraded areas. (These activities are called "in situ" conservation. "Ex situ" conservation, such as occurs in botanical gardens, zoos, and the global network of gene centers, also figures prominently but is clearly secondary. ${ }^{39}$ ) Additionally, the treaty mandates that consideration of biodiversity be included in all aspects of decisionmaking and that governments conduct environmental impact assessments of proposed projects with ramifications for conservation. These commitments, while significant, are modest and did not provoke notable 
debate. For most developed nations, they simply codify existing practices. If implemented properly, the extension of such practices to the developing world could substantially enhance protection of biodiversity, however

\section{Technology and Financial Transfers}

Developing nations insisted that the obligations they undertake be coupled with financial and technical transfers to pay the incremental costs of compliance. In return, developed nations insisted that access to technology and financial transfers only occur subject to mutually agreed terms. The focus on technology transfers further fed fears that the $C B D$ was becoming a grab bag of items linked only tangentially to actual conservation.

The bargaining over financial terms and mechanisms was particularly divisive. The key questions were what specifically would be covered by a biodiversity fund and what body would control it. Developed countries have committed themselves to provide financial resources to developing countries to meet the "agreed full incremental costs" of implementation. The issue of funding incremental costs has appeared in a number of environmental treaties, most notably those on climate change and stratospheric ozone depletion. What exactly constitutes an incremental cost is not defined in the CBD text and this is likely to be a source of considerable disagreement in the future. The pilot phase of the Global Environment Facility (GEF) shows the difficulty of defining and measuring the costs and benefits of biodiversity projects; in practice, the concept may be useless in setting priorities and funding levels. ${ }^{40}$

Developing nations preferred to place the $C B D$ fund under the control of the Conference of the Parties. Donor states adamantly refused, preferring to employ the newly created GEF, which was (and still is to a lesser degree) controlled by the donors. In the end, the donor states won this particular battle, but GEF was only designated the interim mechanism and then only if it was fully restructured to include a "democratic and transparent system of governance." ${ }^{41}$ Yet even at the close of negotiations, ambiguity about the financing terms remained, and the delegations of 19 industrial ized nations joined in a declaration emphasizing their right to determine the amount of their individual and joint contributions. ${ }^{42}$

\section{Biotechnology Regulation and Biosafety}

One of the more controversial elements of the $C B D$ is the commitment to ensure the safety of biotechnology, known as "biosafety." The treaty directs the parties to "establish or maintain means to regulate, manage, or control the risks associated with the use and release of living modified organisms resulting from biotechnology." ${ }^{43}$ For many developed nations (particularly the United States), the linkage between biodiversity and the safety of biotechnology is contrived. Indeed, a UNEP study commissioned in the period preceeding the treaty negotiations found almost no linkages between the two, with those that were found tending to benefit biodiversity. ${ }^{44}$ The treaty text clearly presumes otherwise, however.

The biosafety issue arose late in the negotiations through a proposal from Malaysia that received immediate widespread support from developing countries and many nongovernmental organizations (NGOs). While the biotechnology industry tends to be closely regulated in industrialized countries (mostly through national laws on laboratory practices and the release of living modified organisms outside the laboratory), there are few international regulations governing these activities. The language on biosafety and the specter of possibly draconian international regulation remain sources of consternation for nations actively engaged in biotechnology. These countries perceive biotechnology as an industry with great potential that could be hampered by regulation through an unwieldy global forum with little demonstrated expertise. Despite these concerns, in 1995 the parties agreed to convene a working group to develop a legally binding protocol on biosafety by $1998 .^{45}$

\section{Ownership of Biodiversity}

The CBD consolidates the role of government in protecting and maintaining resources and reaffirms that states have sovereign rights over their own biological resources. ${ }^{46}$ Yet the convention simultaneously propounds a more global view of biological resources, stating that conservation is the "common concern" of all humanity and that states are responsible for using biodiversity in a sustainable manner. The uneasy coexistence between these two aims leaves unresolved how to divide the benefits that flow from biodiversity. The problem is most acute when biological resources have been improved through innovation.

International intellectual property rights (IPR) law-which protects easily copied innovations - became a central issue in the negotiations because even though biological resources from developing countries form the basis for many pharmaceutical, agricultural, and biotechnological innovations, little or none of the resulting profits flow to the source country. ${ }^{47}$ One report estimates that the developing world would gain $\$ 5.4$ billion per year if multinational food, seed, and pharmaceutical firms paid royalties for local knowledge and plant varieties. ${ }^{48} \mathrm{~A}$ few salient examples drive a debate regularly punctuated with terms like "piracy" and "robbery." The Indian neem tree is the source of more than 50 U.S. patents for products ranging from contraceptives to pesticides. Challenges are under way in Europe and the United States to revoke patents issued to W. R. Grace (a major pharmaceutical and chemical firm) on the grounds that its neem-based insecticides and fungicides are not Grace innovations but rather are derived from age-old Indian techniques. ${ }^{49}$

Extending intellectual property rights to genetic innovations is highly controversial. Some, including a diverse group of religious leaders, oppose the patenting of genes-God's innovation-altogether. ${ }^{50}$ Researchers are also concerned about receiving proper rewards for work that leads to patentable innovations. Funding agencies, owners of genetic databases, and researchers are taking steps to develop 
model agreements that protect intellectual property and share the benefits of genetic research. ${ }^{51}$

While Western governments defend IPR law as both just and efficient, many developing nations view it as fundamentally unjust, a means by which resources and wealth are transferred from South to North with the imprimatur of legality. Many have only grudgingly accepted the stricter IPR rules contained in recent trade agreements such as the Agreement on Trade-Related Aspects of Intellectual Property Rights (TRIPS), part of the accord that established the World Trade Organization (WTO). These rules require WTO members to enforce intellectual property rights such as with patents and copyrights. ${ }^{52}$

Through the UN's Food and Agriculture Organization (FAO) and the "farmers' rights" movement, critics have opposed the extension of IPR to seeds and other agricultural products. $^{53}$ The farmers' rights movement stresses the role that farmers-particularly in the South-play in improving plant varieties. The current structure of IPR ignores the slow and incremental improvements wrought by farmers and favors the more identifiable (and sometimes derivative) advances made by large multinational seed firms. The $\mathrm{CBD}$ strikes an uneasy compromise between Northern and Southern views: It commits the parties to cooperate to ensure that patents and other intellectual property rights "subject to national legislation and international law . . . are supportive of and do not run counter to [the CBD's] objectives." ${ }^{154}$ What this means in practice is unclear. The text seems to support the existing IPR structure, but it simultaneously appears to privilege the objectives of the CBD, including the equitable sharing of the benefits from using biological resources. Nonetheless, while IPR was a major negotiating topic in the CBD, how the issue unfolds in other venues, notably the WTO, will probably matter more.

While developing nations face significant hurdles in the revision of international IPR law, they may have greater success reforming access rights to the original biological inputs. Plant genetic resources, for which the arguments are most fully developed, illustrate the major issues. Previous international agreements on the subject, such as the nonbinding FAO Undertaking on Plant Genetic Resources (1983), had enshrined the principle of free access, which enhances the ability of major firms and scientists to obtain genetic inputs without the obligation to share benefits. Issues of access and benefits are central to plant breeding, where the farmers' rights concept first emerged as a counterpart and challenge to plant breeders' rights. Current international law grants extensive protection to plant breeders who improve plant varieties through crossbreeding wild and improved strains. ${ }^{55}$ Negotiations are under way within FAO's Commission on Plant Genetic Resources to develop schemes for benefit sharing that would respect farmers' rights. These negotiations may make more progress than the CBD because they are much more focused, considering only issues related to plants (primarily major food crops). Nonetheless, a system for access and benefit sharing remains elusive. ${ }^{56}$ And, in practice, restricting access to biological resources will be extremely difficult: Although the Chinese kept their silkworm monopoly for many centuries, they ultimately lost it to two enterprising Nestorian monks. ${ }^{57}$

The battle over rights within the $\mathrm{CBD}$ and FAO may threaten the operation of the international network of gene banks and agricultural research centers, though genetic resources held ex situ that were gathered prior to the treaty's entry into force are not covered by the CBD. ${ }^{58}$ These banks have also traditionally operated under a principle of open access to their extensive collections; such access has been instrumental in improving crop yields and disease resistance worldwide. Some of the proposed benefit-sharing schemes would require tracking down the original suppliers of a genetic sample and giving them a portion of the profits from the final product. Given that modern plant hybrids are built on the crossbreeding of hundreds of genetic samples, the feasibility of this approach is limited. The developing countries pushing for such systemswho are already major beneficiaries of the network-are unlikely to realize any appreciable benefit. In short, the $\mathrm{CBD}$ has sown confusion, threatening to overturn existing rules of access; an alternative system has yet to emerge.

While battles over access ensue within UN agencies, private arrangements may become more common. For instance, the pharmaceutical giant Merck gained access to chemical extracts from Costa Rica's National Biodiversity Institute (INBio) in exchange for some $\$ 1.1$ million and an unspecified percentage of future royalties. ${ }^{59}$ Though few similar agreements have emerged thus far, such bilateral deals represent an alternative, though limited, path to the protection of biodiversity. Recent advances in drug design have dramatically reduced the role of large-scale plant screening in providing leads on valuable pharmaceutical. While the expected economic value of the (unknown) genetic resources can provide some incentives for biodiversity protection, it is misguided to expect these concerns to dramatically further such protection.

The debate over access and benefits has raised fundamental questions about the status and ownership of biological resources, as well as the compatibility of Western law, which is based on individual property and market-based exchange, with traditional cultures that pool and exchange knowledge without personal ownership. While these issues are clearly relevant to protecting biodiversity, their inclusion in the CBD significantly raises the stakes and thus the political conflict surrounding the treaty. These debates will be slow and divisive: Now that these issues are on the biodiversity agenda, many expect them to be part of any package deal within the CBD. The protection of biodiversity - the erstwhile aim of the CBD_-will suffer from this conflict.

\section{New Institutions}

In addition to elaborating a set of commitments and goals, the CBD establishes several new international 
institutions to carry out its mandate and continue the cooperative process. The flexible and often vague structure of the treaty's rules and commitments will be animated and focused by debate within these institutions.

\section{Conference of the Parties}

The primary new body is the Conference of the Parties (COP), which makes all formal decisions regarding the treaty. ${ }^{60}$ Formal membership is limited to the actual parties, although important nonparties such as the United States also play a role as observers. The COP has a number of responsibilities that are mentioned specifically in the $\mathrm{CBD}$, including examining new scientific data on biodiversity, examining the issues of liability and redress for damage to biodiversity, defining incremental costs, choosing the appropriate level of financing for the financial mechanism, and considering the need for a biosafety protocol. ${ }^{61}$ Arguably, the main achievement of the $\mathrm{CBD}$ so far has been to create this ongoing body through which global biodiversity issues can be addressed. The COP, which held its first session in 1994, meets annually.

\section{Financial Mechanism}

The CBD includes a provision to transfer financial resources to developing countries to pay the "agreed full incremental costs" of implementation. Because donor states feared the creation of yet another international institution, the CBD will rely on GEF as its interim financial mechanism until at least $1997 .^{62} \mathrm{GEF}$ is already disbursing money on biodiversity projects according to criteria and priorities established by the COP. ${ }^{63}$

According to the CBD's definition, the developed countries consist of the members of the Organisation for Economic Cooperation and Development (OECD) plus Monaco but minus the Czech Republic and Mexico. ${ }^{64}$ An attempt to define developing countries failed; by default the UN list is used. ${ }^{65}$ A third group comprises countries with economies in transition that emphatically declare they are not developing but do not wish to assume the financial obligations of developed countries (though they may voluntarily assume those obligations). Virtually the same distinctions are employed in the climate treaty. ${ }^{66}$ Positions on GEF's council, which governs GEFfinanced activities, are earmarked for developing, developed, and transitional countries. ${ }^{67}$ These distinctions are elastic, however: Several developing countries, including Brazil, China, and Egypt, have been both contributors and recipients of GEF funding.

\section{Clearing-House Mechanism}

As required by the $\mathrm{CBD},{ }^{68}$ the COP has established a clearing-house mechanism to operate in a pilot phase from 1996 to 1997 . The mechanism is charged with promoting international scientific and technical cooperation, disseminating information on the lessons learned during implementation, and facilitating the transfer of technology. ${ }^{69}$ While these functions are important, it remains to be seen if a formal institution can contribute to them effectively; there is little guidance from other international institutions on how to do so. Most technology and information diffuse through markets and scientific collaboration. Absent large resources with which to intervene - such as to fund sorely needed taxonomists in developing countries-the clearing-house mechanism may prove inconsequential.

\section{Secretariat}

The CBD also creates a secretariat to arrange meetings, prepare reports, coordinate with other international organizations, and so forth. ${ }^{70}$ The form and function of this body mirror those of a number of other new secretariats. Secretariats vary in size and effectiveness but are considered necessary components of any comprehensive and complex formal regime. ${ }^{71}$

Many hoped that coordination among secretariats would improve if they were concentrated in Geneva, the interim home of the CBD and climate secretariats as well as several others. In 1995, however, Montreal was chosen as the permanent site for the CBD secretariat, while the climate secretariat is currently in the midst of a move to Bonn. The costs of the CBD secretar- iat (and those of some developing country participants) are covered by a trust fund into which all parties contribute according to a scale of assessments similar to the UN scale.

\section{Advisory Body}

The CBD creates one subsidiary body to provide assistance to the COP as needed. ${ }^{72}$ The Subsidiary Body on Scientific, Technical, and Technological Advice (SBSTTA) is open to all parties and is multidisciplinary in focus. Its tasks are to provide advice and assessments relating to biodiversity, produce policy analyses, and monitor research on biodiversity protection. The SBSTTA cannot take initiatives beyond those necessary to fulfill its mandate and it may only report to the COP itself. In its first year of operation, it has already helped the COP set priorities. Unlike the FCCC, the CBD did not also create a subsidiary body on implementation. Such a body may be needed as national reporting begins and future protocols are negotiated, however.

\section{The Problematic Road Ahead}

The CBD has received a lukewarm reception in international legal and environmental circles, and few supporters have stepped up to defend it. ${ }^{73}$ While its holistic approach breaks some new ground, the treaty is riddled with ambiguity and omission. The implementation and, most importantly, the interpretation of the treaty will matter significantly-perhaps more so than in other, more specific international accords. The CBD is young and perhaps flexible but clearly lacks focus.

\section{Focus and Protocols}

The lack of focus in the treaty reflects the absence of agreement on two major concepts: biodiversity and conservation. With respect to biodiversity, until there is agreement on what is to be protected, it will be difficult to develop effective rules and guidelines for protection. As noted above, differing definitions of diversity yield markedly different policy priorities. Insofar as the treaty aims to protect biodiversity, its future lies less in the development of specific rules than in the consensual 
interpretation of principles, concepts, and obligations. Getting a better handle on biodiversity, improving relevant indicators, and creating an acceptable prioritization of problems will be essential if the treaty is to fulfill its declared mandates.

Conservation is similarly problematic. The CBD endorses the concepts of sustainable use and the sound management of biological resources for human use and betterment. But the treaty's clear statement of the "instrinsic" worth of biodiversity reflects a preservationist view that subsumes human needs within a broader set of ethical concerns. Which vision of conservation will prevail is unclear.

Facing the thorny problems of defining and implementing these central concepts will be crucial if the treaty is ever to become an effective vehicle for the protection of biodiversity. At the moment, the parties appear to be pursuing an alternative strategy to gain focus: the promulgation of protocols. The protocol nearest on the horizon addresses an issue with limited impact on biodiversity (however defined): biosafety and the regulation of biotechnology.

At the second meeting of the COP, the parties agreed to develop a legally binding protocol on biosafety, especially the transboundary movement of living modified organisms (LMOs), by $1998 .^{74}$ Leading biotechnology nations (above all the United States) consider this move unnecessary and an example of the misuse of the treaty process. There is merit to this view: While biosafety may indeed be a topic worthy of international attention, it is not clear why the CBD is the proper venue for it. There is very little evidence that biosafety problems, particularly the transboundary movement of LMOs, represent a serious threat to biodiversity. The 1,016 page Global Biodiversity Assessment, UNEP's official scientific review of the biodiversity issue, devoted a scant nine pages to LMOs and did not mention transboundary movement. The disturbance of ecosystems by "natural" alien species-addressed in the treaty but currently receiving little formal attention-is of far greater importance than that of LMOs. The fact that biosafety is high on the agenda of the CBD while forest issues are sidelined underscores the misguided course of the convention. Pursuing a biosafety protocol is a sure recipe for conflict over an issue that is ultimately of tangential importance to the core goals of the treaty. Such conflict has already cast a shadow on other aspects of the CBD, such as IPR law.

The push for a biosafety protocol is occurring in parallel with the formulation and implementation of nonbinding international guidelines. Developed with the leadership of the United Kingdom and the Netherlands, and now under the auspices of UNEP, these guidelines address the transport and use of genetically engineered products. In September 1995, Argentina became the first developing country to adopt them, in the form of a bilateral agreement with the United Kingdom. Industry remains keen to pursue the voluntary adoption of the guidelines in lieu of a multilateral, binding protocol under the CBD. The specificity and speed of adoption (as well as flexibility) of such voluntary measures may well make them more effective than a legally binding protocol would be. The negotiation of a protocol might even be eclipsed if the guidelines prove highly effective. ${ }^{75}$

Paradoxically, the opposition to a biosafety protocol is likely to lead to its creation. The South, which has little interest in fostering the biotechnology industry, correctly perceives this as an issue with great bargaining potential. The issue thus illustrates one of the pitfalls of the "open-access regime" that characterizes UN diplomacy. Universal participation ensures that the many different concerns and interests of the participants are reflected in the agenda. However, in a loosely conceptualized forum like the $\mathrm{CBD}$, the result can be a "kitchen sink" treaty that addresses any number of concerns not on the basis of their merits but in recognition of the prerogatives of the participants. When consensus on the scope or even the purpose of the accord is missing, wide participation can result in unproductive sidetracking and a loss of focus.
One bright spot in the CBD's effort to achieve focus is the Jakarta Mandate, agreed on at the second COP meeting in 1995 . It requires the creation of an expert group to recommend ways to protect marine and coastal diversity. ${ }^{76}$ If the biosafety initiative stalls, coastal and marine issues could become a central aspect of the CBD's work. More than 75 percent of the world fish catch currently comes from coastal areas, and half the extant phyla of animals live exclusively in marine environments. Pollution, mining and drilling, ozone depletion, climate change, invasions of alien species from ballast, and overfishing are compounding the threats to marine life. ${ }^{77}$ The agenda is broad, but these issues are not adequately covered elsewhere and the CBD could make a substantial contribution.

\section{National Priorities}

The most important actions to conserve biodiversity must be taken at the national level and below. The CBD will make the most progress by fostering a decentralized process in which nations identify areas for policy action, set standards, and report their actions within the CBD framework. A system of national planning and reporting coupled with systematic international review can promote such a process, helping countries to focus their priorities and learn from each other's successes and failures. While the experience with review systems has been mixed, the climate regime has developed a fairly sophisticated national reporting system that appears to be functioning well. ${ }^{78} \mathrm{~A}$ similar system could do much to alleviate the problems of the CBD. Yet a well-funcioning system of national reports would also shed glaring light on the difficulties of the convention as drafted, highlighting the ambiguities it contains. The first steps are thus critical for the evolution of the regime.

The CBD requires countries to submit reports, and in 1995 the parties finally agreed to loose guidelines for their preparation. ${ }^{79}$ The first reports, due in 1997, will focus on national measures to implement the CBD's obligations to promote conservation 
and the sustainable use of biodiversity. It is disappointing that these steps were not taken earlier-UNEP developed guidelines for the preparation of country studies and inventories in $1993{ }^{80}$ WRI and IUCN have also been active in helping nations prepare studies and plans. ${ }^{81}$ Thirty-four countries have initiated national biodiversity studies, nearly half of which are already complete. Connecting this work to the formal CBD process must now wait until at least 1997. SBSTTA will oversee the reporting process.

Perhaps the most impressive product of the biodiversity regime has been the comprehensive Global Biodiversity Assessment released at the second COP meeting. It is similar in purpose to the two assessments conducted by the better known Intergovernmental Panel on Climate Change associated with the climate regime. Observers of the two conventions will learn much about the role and influence of science by comparing these two analogous efforts.

\section{Forests}

Forests are perhaps the single most important repository of biodiversity (other contenders include coral reefs and the oceans). ${ }^{82}$ Yet the issue of forests has been delicately skirted by the parties to the CBD. Brazil, Malaysia, and other nations with vast (but shrinking) tropical forests are deeply suspicious of efforts to address internationally what they consider to be sovereign domestic resources. Many developing countries feel that the issue of forests is and should be addressed elsewhere. Several large NGOs have suggested a forests protocol, but the proposal appears dead on arrival.

The Commission on Sustainable Development, a UN body created in the wake of UNCED, has established an Intergovernmental Panel on Forests, to which the CBD has made a formal statement on the importance of forest biodiversity. ${ }^{83}$ The panel was organized by Canada and Malaysia, two countries that many environmental groups consider the worst despoilers of forest lands. Forestry is on the agenda in more than a dozen other fora as well. At the official governmental level, members of the International Tropical Timber
Organization recently adopted new agreements for timber management. ${ }^{84}$ In addition, various smaller initiatives aimed at European forests, temperate and boreal forests, and so on are under way. At the private level, among several others, is the World Commission on Forests and Sustainable Development, begun in $1992{ }^{85}$ Forests will again be on the CBD agenda in 1997, but these alternative fora have enabled countries critical of CBD's involvement with forests to claim that the issue is being adequately addressed elsewhere. The forests issue helped catapult the biodiversity problem to prominence, but it has also led forested nations, especially in the tropics, to be wary of international biodiversity efforts. Because forests provide so much critical habitat, however, they are a proper if not central concern of any treaty designed to protect biodiversity. Failing to address forests within the CBD is akin to failing to address coal within the convention on climate change.

\section{U.S. Ratification}

Although the United States was the single most important nation in the negotiation of the CBD, it currently remains outside the treaty. While the United States is not especially rich in biodiversity, its participation in any international environmental accord is important. It has one of the world's best developed systems of wildlife preservation, and U.S. expertise (channeled through a well-developed system of national reporting and review) could significantly improve the standards, national inventories, and programs of other parties. The central position of the country's biotechnology industry also makes U.S. participation critical. Without it, there is a real danger that U.S. interests themselves will be harmed: Soon after the U.S. decision not to sign the CBD, Venezuela stopped signing new agreements with U.S. scientific institutions interested in gathering biological materials in Venezuelan forests. ${ }^{86}$

One year after UNCED, President Clinton signed the CBD, reversing the position of President Bush. Although partly a response to shifting political winds, this move also reflected a reap- praisal of the merits of U.S. participation by the pharmaceutical and biotechnology industries. These industries, which initially supported the decision to reject the treaty, are now strongly in favor of ratification. ${ }^{87}$ They perceive the risks of staying out-and thereby allowing a biosafety protocol to be developed without U.S. inputas being greater than joining. However, the treaty remains unpopular in conservative circles. Various senators have expressed concern about a number of the CBD's provisions, especially its effect on domestic legislation (such as the Endangered Species Act, which will be reauthorized soon and is likely to be weakened). ${ }^{88}$ Many members of Congress are also concerned about the vagueness and ambiguity of the text. ${ }^{89}$ At the moment, ratification of the treaty is in limbo.

\section{Conclusion}

For better or worse, the CBD's agenda is much larger and more ambitious than global conservation. There is cause for hope, however: The system of national reports should help set priorities and focus activities, and the Jakarta Mandate directs attention to the critical and insufficiently addressed issue of marine biodiversity. But as an instrument for preserving biodiversity, the $\mathrm{CBD}$ has serious problems at both the grand level of principles and the practical level of implementation. Pressure to address these problems is lacking for several reasons. First, a significant body of wildlife and ecosystems law already exists, which to some extent takes the heat off the CBD. Second, the loss of biodiversity is largely invisible. There is little of catastrophic import-like the melting of the Antarctic ice shelf-to seize the public imagination or keep governments concerned. Third, the $\mathrm{CBD}$ has long been eclipsed by the FCCC and this is unlikely to change. For governments, NGOs, and UN agencies alike, biodiversity is still minor-league environmental diplomacy.

For these reasons, a special effort must be made to move the CBD in a positive direction. The ambiguity of 
the treaty can become a virtue in the hands of skilled negotiators and committed governments. This will not occur, however, without a sustained focus on core conservation issues as opposed to sidelines like biosafety. Without that focus, the treaty will probably fall victim to the endless conflicts that plagued the Law of the Sea negotiations - and that is unlikely to provide security for the Earth's biological resources.

\section{ACKNOWLEDGMENTS}

The authors thank Lyle Glowka and Chris Stone for helpful comments on this paper, Nina Drinković, Aviott John, and Eddie Löser for help with references, and the secretariat of the Convention on Biological Diversity for their assistance.

\section{NOTES}

1. "Convention on Biological Diversity," Rio de Janeiro, 1992, in International Legal Materials 31 (1992): 818

2. For an overview of the biodiversity problem, see E. O. Wilson, ed., Biodiversity (Washington, D.C.: National Academy Press, 1988); and B. Groombridge, ed., Global Biodiversity: Status of the Earlb's Living Resources (New York: Chapman and Hall, 1992). For an up-to-date assessment, see B. H. Heywood and R. T. Watson, eds., Global Biodiversity Assessment (Cambridge, U.K.: Cambridge University Press, 1995).

3. See D. L. Hawksworth et al., "Magnitude and Distribution of Biodiversity," in Heywood and Watson, note 2 above, page 107.

4. R. Barbault et al., "Generation, Maintenance, and Loss of Biodiversity," in Heywood and Watson, note 2 above, page 193.

5. The extinction rate may be even higher for plants. See E. O. Wilson, "The Current State of Biological Diversity," in Wilson, note 2 above, page 3.

6. N. Myers, "Tropical Forests and Their Species: Going, Going...?" in Wilson, note 2 above, page 28. 7. S. L. Pimm et al., "The Future of Biodiversity," Science 269 (21 July 1995): 347

8. W. Beckerman, Small is Stupid: Blowing the Whislle on the Greens (London: Duckworth, 1995), 71. 9. R. Stone, "Proposed Global Network for Ecology Data Stirs Debate," Science 266 (18 November 1994): 1155 .

10. See C. J. Humphries, P. H. Williams, and R. I. Vane-Wright, "Measuring Biodiversity Value for Conservation," Annual Review of Ecology and Systematics 26 (1995): 93.

11. J. A. McNeely et al., "Human Influences on Biodiversity," in Heywood and Watson, note 2 above, page 711 .
12. D. Skole and C. Tucker, "Tropical Defores. tation and Habitat Fragmentation in the Amazon: Satellite Data from 1978 to 1988 ," Science 260 (25 June 1993): 1905-10; and D. Tilman et al., "Habitat Destruction and the Extinction Debt," Nalure 370 (1 September 1994): 66.

13. Tilman, note 12 above; and $\mathrm{S}$. Robinson et al., "Regional Forest Fragmentation and the Nesting Success of Migratory Birds," Science 267 (31 March 1995): 1987-90

14. Many of these are in the form of public goods. See C. Stone, "What to Do About Biodiversity: Property Rights, Public Goods, and the Earth's Biological Riches," Soubern California Law Review 68, no. 3 (March 1995): 577.

15. For example, undiscovered pharmaceuticals are often perceived as a gold mine hidden within moist tropical forests. Yet the total value of all undiscovered tropical forest pharmaceuticals has been estimated to be only about $\$ 150$ billion or $\$ 48$ dollars per hectare. Moreover, this figure is the social value, not the value to a private company. The latter is only $\$ 3$ billion or about $\$ 1$ per hectare. R. Mendelsohn and M. Balick, "The Value of Undiscovered Pharmaceuticals in Tropical Forests," Economic Botany 49, no. 2 (1995): 223-28.

16. For a discussion of the agricultural and industrial benefits from plant diversity, see $M$ Plotkin, "The Outlook for New Agricultural and Industrial Products From the Tropics," in Wilson, note 2 above.

17. C. M. Peters, A. H. Gentry, and R. O Mendelsohn, "Valuation of an Amazonian Rain Forest," Nalure 339 (26 June 1989): 655-56.

18. R. Godoy, R. Lubrowski, and A. Markandya, "A Method for Economic Valuation of Non-Timber Tropical Forest Products," Economic Botany 47, no. 3 (1993): 220-33.

19. R. MacArthur, "Fluctuations of Animal Populations and a Measure of Community Stability," Ecology 36 (1955): 533-36; C. S. Elton, The Ecology of Invasions by Animals and Plants (London: Chapman and Hall, 1958); and S Pimm, "The Complexity and Stability of Eco systems," Nature 307 (26 January 1984): 321-26. 20. S. Naeem et al., "Declining Biodiversity Can Alter the Performance of Ecosystems," Nature 368 (21 April 1994): 734; and D. Tilman et al. "Productivity and Sustainability Influenced by Biodiversity in Grassland Ecosystems," Nature 379 (1996): 718.

21. D. Pearce, Economic Values and the Natural World (London: Earthscan, 1993); and K. Brown and D. Moran, "Valuing Biodiversity: The Scope and Limitations of Economic Analysis," in V. Sánchez and C. Juma, eds., Biodiplomacy (Nairobi, Kenya: ACTS Press, 1994). A brief survey of the value of biodiversity is found in J. A. McNeely, K. R. Miller, W. V. Reid, R. A. Mittermeier, and T. B. Werner, "Strategies for Conserving Bio diversity," Environment, April 1990, 16.

22. For a broader argument against the applica tion of economic methodology to environmental issues, see M. Sagoff, The Economy of the Earth: Philosopby, Law, and Environment (Cambridge, U.K.: Cambridge University Press, 1988).

23. Derived from J. Rawls, A Theory of Justice (Cambridge, Mass.: Harvard University Press, 1971). For an application to international environ- mental issues, including biodiversity, see E. B Weiss, In Faimess to Future Generations (Dobbs Ferry, N.Y.: Transnational Publishers, 1989); and E. B. Weiss, "In Fairness to Future Generations," Environment, April 1990, 6.

24. The preamble to the convention begins with the words "Conscious of the intrinsic value of biological diversity." "Convention on Biological Diversity," note 1 above, page 822 .

25. This treaty was the first biodiversity-related treaty in force but it has been superseded by the 1950 Paris Convention for the Protection of Birds. See P. Sands et al., eds., Documents in International Environmental Law (Manchester, U.K. Manchester University Press, 1994), 732; and P. Birnie and A. Boyle, International Law and the Environment (Oxford, U.K.: Oxford University Press, 1992).

26. See S, Lyster, International Wildlife Law (Cambridge, U.K.: Grotius, 1985). These lists identify priority areas and help organize the efforts of the various regimes.

27. W. V. Reid and K. R. Miller, Keeping Options Alive: The Scientific Basis for Conserving Bio diversity (Washington, D.C.: World Resources Institute, 1989); J. McNeely et al., Conserving the World's Biodiversity (Gland, Switzerland: World Conservation Union); and World Resources Institute, World Conservation Union, and United Nations Environment Programme, Global Biodiversity Sirategy (1992). Since the early 1990s, these groups have given attention to the need for country studies to contribute to future assessment efforts. See United Nations Environment Programme, Guidelines for Country Studies on Biological Diversity (Nairobi, Kenya, 1983). For a preliminary assessment and overview, see World Resources Institute, World Conservation Union, and United Nations Environment Programme, National Biodiversity Planning: Guidelines Based on Early Experiences Around the World (Washington, D.C.: World Resources Institute, 1995).

28. For histories of the negotiations, see $J$. McNeely, M. Rojas, and C. Maronet, "The Convention on Biological Diversity: Promise and Frustration," Joumal of Environment \& Development 4, no. 2 (1995): 33; W. Burhenne, forward to Sánchez and Juma, note 21 above, page ix; V Sánchez, "The Convention on Biological Diversity: Negotiation and Contents," in Sánchez and Juma, note 21 above, page 7; C. de Klemm, Biological Diversity Conservation and the Law (Gland, Switzerland and Cambridge, U.K.: World Conservation Union, 1993); and L. Glowka, P. Burhenne-Guilmin, and $\mathrm{H}$. Synge in collaboration with J. A. McNeely and L. Gündling, $A$ Guide to the Convention on Biological Diversity, Environmental Policy and Law Paper No. 30 (Gland, Switzerland and Cambridge, U.K.: World Conservation Union, 1994). Many official documents and updates are available from the secretariat at http://www. unep.ch/biodiv.html. For updates on $\mathrm{CBD}$ meetings, see the Earth Negotiations Bulletin at http://www.iisd.ca./ linkages/biodiv.html.

29. F. B. Golley, A Hislory of the Ecosystem Concept in Ecology: More Than the Sum of the Parts (New Haven, Conn.: Yale University Press, 1993). The idea for a global treaty, however, dates from the 1940 s; see de Klemm, note 28 above, pages 7-8. 
30. See D. H. Janzen, "The Future of Tropical Ecology," Annual Review of Ecology and Systematics 17 (1986): 305

31. This notion comes from J. Kingdon, who argues that policy "entrepreneurs" have a ready supply of solutions that they promote during the windows of opportunity that come along when disconnected streams of politics and ideas merge. See J. Kingdon, Agendas, Alternatives, and Public Policies (Boston: Little, Brown, 1984)

32. UNEP Resolution 14/26, adopted in 1987 , established an ad hoc working group to explore an "umbrella convention to rationalise current activities" related to biodiversity protection. IUCN adopted similar resolutions in 1984 and 1987

33. See J. Sebenius, Negotiating the Law of the Sea (Cambridge, Mass.: Harvard University Press, 1984); and S. Krasner, Structural Conflict: The Third World Against Global Liberalism (Berkeley, Calif.: University of California Press, 1985).

34. Conservatives perceived U.S. accession to the $\mathrm{CBD}$ as a possible legal and political threat to their efforts to roll back land-use and environmental legislation.

35. The CBD's treatment of these issues parallels the debates within the Food and Agriculture Organization on plant genetic resources. See J. Kloppenburg, ed., Seeds and Sovereignty (Durham, N.C.: Duke University Press, 1988).

36. The other developed countries were Canada, Australia, New Zealand, and Norway.

37. Frank Njenga, Asian-African Legal Consultative Committee, quoted in E. Diringer, "Why US Opposes Biodiversity Pact," San Francisco Chronicle, 9 June 1992, A7.

38. Articles 6 and 8 .

39. Article 9 .

40. For case studies of the incremental cost concept in practice, see I. A. Bowles and G. Prickett, Reframing the Green Window: An Analysis of the GEF Pilot Phase Approach to Biodiversity and Global Warming and Recommendations for the Operational Phase (Washington, D.C.: Conservation International and Natural Resources Defense Council, 1994).

41. Articles 20 and 21 address financial resources and the financing mechanism. GEF was restructured in 1994.

42. "Declaration Made after the Adoption of Agreed Text of the Biodiversity Convention," UNEP NA 92-8314 (1992).

43. Article 19

44. L. V. Giddings and G. Persley, Biotechnology and Biodiversity, UNEP/Biodiv/SWGB.1/3 (United Nations Environment Programme, October 1990). 45. COP Decision II/5, available on the World Wide Web, note 28 above

46. This principle has been affirmed in a number of UN resolutions as well as other treaties.

47. For overviews, see Kloppenburg, note 35 above; Office of Technology Assessment, Biotechnology in a Global Economy, OTA-BA-494 (Washington, D.C., 1991); and the Crucible Group, People, Plants, and Patents (Ottawa, Canada: International Development Research Centre, 1994). For a U.S.-based analysis of IPR and biotechnology, see C. Hardy, "Patent Protection and Raw Materials: The Convention on Biological Diversity and Its Implications for U.S. Policy on the Development and Commercialization of Biotechnology," Univerrity of Pennsylvania Joumal of Intemational Business Law (1994).

48. United Nations Development Programme, Conserving Indigenous Knowledge: Integrating Two Systems of Innovation (New York, 1994), reported in F. Williams, "Bio-piracy costs Third World \$5.4bn a year," Financial Times, 28 October 1994. 49. D. Dickson and K. S. Jayaraman, "Aid Groups Back Challenge to Neem Patents," Nature 377 (14 September 1995): 95. Another native Indian plant, Rauwolfina serpentina, provides raw material for a hypertension drug with $\$ 260$ million in U.S. sales annually, yet none of the profits flow back to India; see K. S. Jayaraman, "India Set to End Gene Robbery," Nature 370 (25 August 1994): 587.

50. E. Andrews, "Religious Leaders Gear Up for Battle on Gene Patents," International Herald Tribune, 15 March 1995, 1.

51. G. Poste, "The Case for Genome Patenting," Nature 378 (7 December 1995): 534-36.

52. "Agreement on Trade-Related Aspects of Intellectual Property-Rights, Including Trade in Counterfeit Goods," Final Act Embodying the Results of the Uruguay Round of Multilateral Trade Negotiations, MTN/FA II-AIC (15 December 1993)

53. See V. Shiva, "Farmer's Rights and the Convention on Biological Diversity," in Sánchez and Juma, note 21 above, page 107. For a broader discussion of IPR in the developing world, see S Sell, "Intellectual Property Protection and Antitrust Policy in the Developing World: Crisis, Coercion, and Choice," International Organization 492, no. 2 (1995): 315.

54. Article 16.

55. Breeders are protected under many national patent regimes as well as an international convention under the auspices of the International Union for the Protection of New Varieties of Plants. For an overview, see Stone, note 14 above. 56. While a small farmers' rights fund has been set up by the Food and Agriculture Organization, no cash has yet been disbursed.

57. Even a strict ownership regime would face the problem of smuggling, which, in the case of genetic resources, is both easy and old. See Stone, note 14 above, pages 602-05; and Paul Raeburn's account of Thomas Jefferson's smuggling of rice from Italy in The Last Harvest: The Genetic Gamble that Threatens to Destroy American Agriculture (New York: Simon \& Schuster, 1995).

58. These banks, which have enormous stocks of plant genes, are managed by the Consultative Group on International Agricultural Research (CGIAR). The fact that previously existing stocks are not covered by the CBD may limit the treaty's ability to change rules of access. See M. S. Swaminathan, "Seeds and Property Rights: A View From the CGIAR System," in Kloppenburg, note 35 above. New samples are being collected under bilateral arrangements that preserve the principle of open access. See J. H. Barton and W. E. Siebeck, Material Transfer Agreements in Genetic Resource Exchange, Issues in Genetic Resources No. 1 (Rome: International Plant Genetic Resources Institute, 1994). For a fact-filled account of the role of gene banks and crossbreeding in improving crop yields, see D. L. Plucknett et al., Gene Banks and the World's Food
(Princeton, N.J.: Princeton University Press, 1987.)

59. See E. Blum, "Making Biodiversity Conservation Profitable: A Case Study of the Merck/INBio Agreement," Environment, May 1993, 16; and W. Reid et al., Biodiversity Prospecting: Using Genetic Resources for Sustainable Development (Washington, D.C.: World Resources Institute, 1993). Other arrangments for plant screening exist; see B. Aylward, "The Role of Plant Screening and Plant Supply in Biodiversity Conservation, Drug Development and Health Care," in T. Swanson, ed., Intellectual Property Rights and Biodiversity Conservation (Cambridge, U.K.: Cambridge University Press, 1995).

60. Article 23

61. Tbid.

62. There is disagreement over the exact relationship, which will be codified in a memorandum of understanding between GEF and the CBD. A draft exists, but at both the first and second COP meetings a final decision was postponed. See D. Pruzin, "Treaty Parties Fail Again in Effort to Set Up GEF in Permanent Financing Role," International Environment Reporter, 29 November 1995, 898-99.

63. The recent restructuring of GEF has made it more attractive as a financial mechanism for conventions such as the CBD. GEF is explicitly required to follow the "policies, program priorities and eligibility criteria" decided by the COP of each convention. See Global Environment Facility, Instrument for the Establishment of the Restructured Global Environment Facility (Geneva, 1995), paragraphs 6,26 , and 27.

64. COP Decision I/2, in Report of the First Meeting of the $[\mathrm{COP}]$ to the Convention on Biological Diversity, UNEP/CBD/COP/1/17 (1995); see the World Wide Web address in note 28 above. 65. See United Nations Development Programme, Human Development Report 1994 (New York: Oxford University Press, 1995), 225. 66. "UN Framework Convention on Climate Change," New York, 1992, in International Legal Materials 31 (1992): 849

67. Global Environment Facility, note 63 above

68. Article 18

69. These functions are described in Decision II/3 of the COP; see the World Wide Web address in note 28 above

70. Article 24

71. R. Sanford, "International Environmental Treaty Secretariats: Stage Hands or Actors?" in H. O. Bergesen and G. Parmann, eds., Green Globe Yearbook 1994 (New York: Oxford University Press, 1994) provides an overview.

72. Article 25

73. For example, M. Chandler, "The Convention on Biological Diversity: Some Issues for the International Lawyer," Colorado Journal of International Envirommental Law 4, no. 2 (1993): 174 notes that "the text should cause the utmost distress for international lawyers and policymakers." See also Boyle, note 28 above. For some NGO criticisms and a defense of the treaty, see V. Sánchez, "The Convention on Biological Diversity: Negotiation and Contents," in Sánchez and Juma, note 21 above, page 7 . Sánchez was the chair of the intergovernmental committee that negotiated the convention. 
74. COP Decision II/5.

75. D. Dickson, "Biosafety Code Gathers Pace Through Bilateral Agreements," Nature 377 (14 September 1995): 94.

76. D. Pruzin, "COP-2 Agrees on Biosafety Protocol, Initiative on Marine, Coastal Biodiversity," International Environmental Reporter, 29 November 1995, 897-98.

77. H. A. Mooney et al., "Biodiversity and Ecosystems Functioning: Ecosystems Analyses," in Heywood and Watson, note 2 above, pages 326. 452 .

78. See D. Victor and J. Salt, "From Rio to Berlin: Managing Climate Change," Environment, December 1994, 6. There has been very high compliance with the requirement that parties submit national reports ("communications"). A broad view of these reports was completed in December 1994. Since then, a process of in-depth reviews has been under way. By February 1996, 31 national reports had been submitted and 17 indepth reviews had been completed.

79. Article 26; Decision II/7 of the COP and Recommendation I/5 of the SBSTTA.

80. United Nations Environment Programme, Guidelines for Country Studies on Biological Diversity (Nairobi, Kenya, 1993).

81. World Resources Institute, United Nations Environment Programme, and World Conservation Union, National Biodiversity Planning Guidelines Based on Early Experiences Around the World (Washington, D.C., 1995).

82. T. C. Whitmore, R. Peralta, and K. Brown, "Total Species Count in a Costa Rican Tropical Rain Forest," Joumal of Tropical Ecology (1985) counted 223 species of vascular plants (or one sixth the total number of plant species in the British Isles) in a 100 square meter plot. The oceans contain the greatest array of phylum diversity. See C. Ray, "Ecological Diversity in Coastal Zones and Oceans," in Wilson, note 2 above, page 36 .

83. See Decision $\Pi / 9$ of the COP

84. D. Pitt, "Forest Preservation is Agreed On at UN," International Herald Tribune, 24 January 1994, 10

85. For updates and a review of international forestry initiatives, consult the "Year in Review" in G. Handl, ed., Yearbook of International Environmental Law (New York: Oxford University Press, annually) or visit http://www/iisd.ca/linkages/ forestry/forest.html on the World Wide Web.

86. W. Reid, "Bush Biodiversity Policy Risks Dangerous Side Effects," Wall Street Journal, 8 October 1992.

87. Letter from the presidents of the Biotechnology Industry Organization, the American Seed Trade Association, and the Pharmaceutical Research and Manufacturers of America to Senator Kent Conrad (D-N.D.), 8 August 1994

88. See "Endangered Species: Nature, Nurture, and Property Rights," The Economist, 8 July 1995 , 54-55.

89. Letter from the Senate Committee on Foreign Relations to majority leader George Mitchell (D-Me.), 5 August 1994; and reply from Secretary of the Interior Bruce Babbit, Secretary of Agriculture Mike Espy, and Secretary of State Warren Christopher, 16 August 1994. 
